\title{
良性の様相を呈した舌血管肉腫
}

\author{
小笠原健文・白川正順・坂井陳作 \\ 岩本正生・宮原康郎·田所 衛*
}

\section{A case of angiosarcoma of the tongue suspected to be a benign tumor}

\author{
Takafumi Ogasawara $\cdot$ Masayori Shirakawa $\cdot$ Nobuoki SakaI \\ Masao Imamoto • Yasuo Miyahara • Mamoru Tadokoro*
}

\begin{abstract}
Marignant hemangiosarcoma is relativcly rare in the oral cavity. Here we describe a case of malignant hemangiosarcoma of the tongue suspected to be a benign tumor.

Our case was a woman 72 years of age who noticed the lesion several weeks previously as a bean-sized swelling on her tongue. The tumor was dark red and measured $8 \times 5 \times 5 \mathrm{~mm}$. The surface was smooth and elastic hard. It was tender, but not pulsating. As the tumor was partially necrotic, it was resected, with a surgical margin of $5 \mathrm{~mm}$. The pathological diagnosis of the specimen was malignant hemangiosarcoma. Whole-body scintigraphy and CT scan showed no abnormalities.
\end{abstract}

At present, 2 years and 2 months after operation, there is no evidence of local recurrence or distant metastasis.

Key words: Angiosarcoma (血管肉腫), Hemangioendothelioma（血管内皮腫）, Tongue（舌）

緒言

血管腫の悪性型は, 一般に血管肉腫 (Hemangiosarcoma）と呼ばれ，血管内皮細胞から発生するきわ めてまれな腫锽である. 顎顔面口腔領域では㚘部, 上 顎歯肉部の血管肉腫の報告があるが 1,2$)$, 舌はきわ めて少ない 3,4$)$.

今回, 舌に生じ良性腫瘍の様相を呈した血管肉腫の 1 例を経験したので若干の考察を加えその概要を報告 する.

町田市民病院口腔外科

(主任 : 白川正順医長)

*聖マリアンナ医科大学病理学教室

(主任 : 田所 衛教授)

Department of Oral and Maxillofacial Surgery, Machida City Hospital (Chief: Dr. Masayori Shirakawa)

*Department of Pathology, St. Marianna Medical University (Chief: Prof. Mamoru Tadokoro)

受付日：平成 5 年 10 月 20 日
症例

患 者: 歳, 女性.

初 診: 平成 3 年 6 月 $\square$ 日.

主 訴: 左側舌縁部の接触痛.

家族歴および既往歴 : 特記事項なし.

現病歴 : 約 1 週間前から義歯装着時に左側舌縁部に 疼痛を自覚したため, 某歯科を受診したところ, 同医 にて左側舌縁部の血管腫を指摘され，当科紹介され来 院した.

現 症 : 全身状態は体格栄盖とも中等度で特記すべ き事項は認められなかった. また, 所属リンパ節の腫 脹は認められなかった， 口腔内所見では，左側舌縁部 に暗赤色, 境界明暸な直径約 $8 \mathrm{~mm}$ 大の半球形腫瘤を 認めた。表面は滑沢, 易出血性で硬さは弾性硬, 圧痛 を認め, 腫湯と連続した部位に一部癞痕様の硬結を触 知した。

臨床診断 : 舌腫場.

処置および経過 : 平成 3 年 6 月口日初診時, 舌腫瘍 の臨床診断のもと腫場摘出を予定した。 6 月ロ日手 


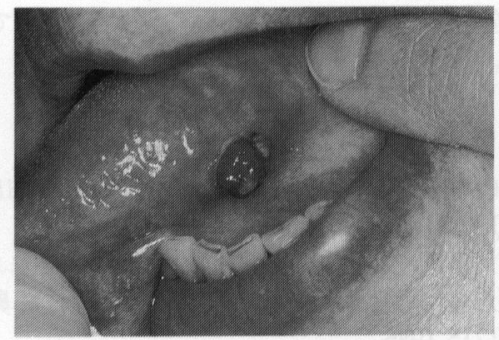

写真 1 術前口腔内写真

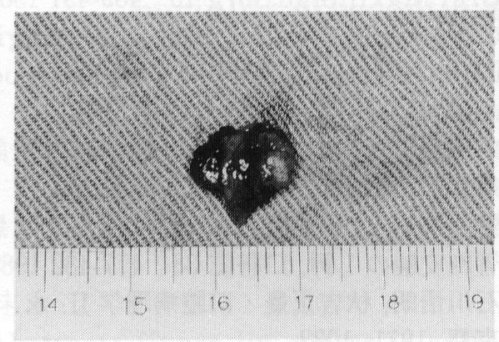

写真 2 切除物写真

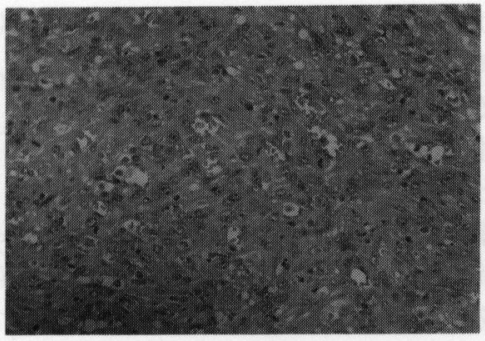

写真 3 病理組織像 (H-E 染色 弱拡大)

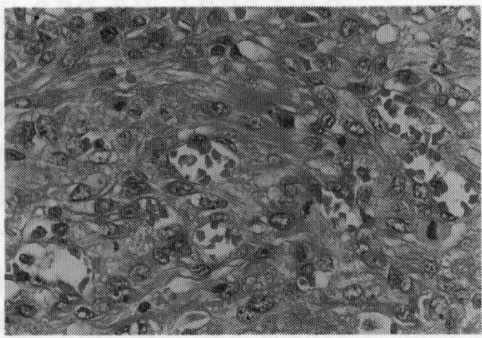

写真 4 病理組織像（H-E 染色 強拡大）
術時, 腫瘍は増大傾向を示し一部に壊死を認めたため (写真 1 )，5 mm のサージカルマージンを設定し周囲 健康組織を含め腫瘍を切除した. 病理組織学的に検索 したところ，血管肉腫との診断を得たためただちに全 身精査を行った，Ga シンチグラムで全身および頭頸 部に異常集積は認められず，また，CT 所見でも明ら かなリンパ節の腫脹は認められなかった、約 2 年 2 か 月を経過した現在局所再発および遠隔転移の徴候を認 めず経過は良好である。

摘出物所見：腫瘍は直径 $12 \times 7 \mathrm{~mm}$ で暗赤色,一部 薄い被膜に覆われていた. 硬さは弾性硬で表面は軽度 に凹凸がみられた（写真 2 )。

病理組織学的所見 : 弱拡大では腫瘍細胞が大小多数 の血管腔を形成し, 異型性の強い細胞を認めた。強拡 大では, 腫瘍細胞は密に増殖し, 散在する核分裂像が 認められた。また, 腫瘍組織は核質が一様に分布した 類円形の核と，好酸性のやや豊富な胞体を有する腫大 した内皮細胞よりなっており，不規則に吻合する血管 腔を形成していた（写真 $3 ， 4)$.

\section{考察}

血管肉腫は血管内皮細胞から発生するきわめてまれ な腫瘍である，発生部位は頭皮をはじめとして肝，脾， 肺, 腸管など脈管の存在するいかなる組織からも発生 しうる $\left.{ }^{5}\right)$. 顎顔面口腔領域では上下顎骨, 上顎洞, 歯 肉，口唇，皮膚などの報告が散見された程度で 6 ），特 に舌は稀少である $\left.{ }^{3}, 4\right)$ ，元来口腔領域における肉腫 の発現頻度そのものが癌腫に較べてはるかに少なく，
口腔悪性腫瘍全体の $10 \%$ 程度といわれている ${ }^{6)}$.また 口腔領域に発現する肉腫の特徴として, 発生部位は顎 骨が主で軟組織に少ないこと，組織学的には，悪性リ ンパ腫, 骨原性肉腫, 線維肉腫が大部分を占めている7 ${ }^{7}$.

血管原性悪性腫瘍の分類法は, 統一した見解がなく, 諸説がある. Stout ${ }^{8)}$ は主たる構成細胞から，血管内 皮腫, 血管周皮腫, Vascular form of Leiomyosarcoma, カポジ肉腫の 4 つに分類し, 木村 $\left.{ }^{9}\right)$ は, 血管系 腫瘍を組織像から，5つの型に分類している。すなわ ち，1）細管性：腫瘍主成分が細血管像が明らかなも の，2）豊細胞型（血管芽腫）：細管像不明で腫痬細 胞大部分が不規則集合状，3）血管肉腫：細胞形が乱 雑化し, 多形性強い，4）蔓状血管腫：やや大きい動 静脈管の迁曲集合状のもの，5) 特異型：血管は多い が, 他の組織や細胞成分が混在しあるいは組織像も血 管腫としてやや例外的なもの，としている。また石川 $5^{7)}$ は, 悪性血管内皮腫, 悪性血管周皮腫, カポジ肉 腫の 3 つに分類している。一方猿田 ${ }^{10)}$ は，脈管肉腫を 血管肉腫と、リンパ管肉腫（悪性リンパ管内皮細胞腫） に大別し，そのうち前者を悪性血管内皮細胞腫，悪性 血管外皮細胞腫, カポジ肉腫, その他のものに細分類 した。

本腫瘍の発生原因は明らかでないが, 先天性のも $の^{11)}$ と外傷性のもの ${ }^{12)}$ が考えられ, 外傷部位の肉芽 の毛細血管から発生したり $8 ， 13 ， 14 ＼mathrm{~ ， 血 管 腫 に 外 傷 ま ~}$ たは感染を生じ, 悪性化するとも考えられている ${ }^{15)}$. この点について前山ら 16) は外傷は直接原因とは考え がたくむしろ腫瘍の悪性化を誘発, 促進する一因と考 
えた方が妥当であると述べている. 自験例では同部は 義歯の刺激が長期に加わっていた痕跡があり，腫瘍と 連続する一部に若干硬結を伴っていたことなどから瘷 痕肉芽組織内の内皮細胞が悪性化し血管肉腫に変化し たものと推察した。

本腫瘍は鑑別診断が困難といわれている．その理由 は臨床病態像が単発性で, 境界が明瞭でいかにも良性 の様相を呈するからである. そのうえ，生検で非悪性 腫瘍と診断されても良性と悪性とが混在する場合が少 なくなく, 全割切片ではじめて血管肉腫と病理診断さ れた例がある.そのため全切除によって最終診断を委 ねるべきである。これらの点から電子顕微鏡的診断を 勧めるものもいる17).

治療法についてはまだ報告例が少なく，通例化した といえるものはない. Farr ら ${ }^{12)}$ は放射線治療につい て本腫瘍は放射線感受性が高いが, 根治的放射線療法 が可能ではないと述へ, 化学療法ではブレオマイシン, エンドキサンなどで一時的に奏効したとの報告 ${ }^{15)}$ が あるが，その有用性については言及できる段階ではな い. したがって, 本腫瘍の治療法は現段階では手術を 第一選択とするのが最良であろう.

自験例では良性腫晹の様相を呈していたが，急激に 腫瘍が増大し一部に壊死を認めたため悪性腫場を疑い 比較的広い範囲で切除した，その結果, 血管肉腫の病 理組織診断を得たため得策であったと思われた，RI， $\mathrm{CT}$ 検査など諸検査を追加したが他部位, 他臓器への 転移, 異常は認められなかった。また切除は $5 \mathrm{~mm} の$ サージカルマージンを設定して周囲健康組織を含め切 除を行った. 病理組織学的に周囲組織への浸潤を認め なかったため, 術後照射, 化学療法については行わな かった. 約 2 年 2 か月を経過した現在, 再発, 転移など を認めず, 経過はきわめて良好である.

以上のごとく, 本腫瘍は一見良性腫瘍を思わせても 悪性であることが多い。一般にはその臨床所見から看 過されることがあるが, この点を十分留意しなければ ならない. 小腫瘤であったとしても病理組織学的検索 が必須と思われた. 本腫瘍は血管系の腫瘍であり全身 どの部位に発生しても不思議はない.したがって, 自 験例においても今後定期的な精査, 経過観察が必須と 考えられた。

\footnotetext{
今回われわれは藏女性の舌に発生し, 良性腫瘍
}

の様相を呈した血管肉腫の 1 例を経験したので報告し た.

\section{引用文 献}

1）山本祐三 : 右煩部に原発した悪性血管内皮腫の 1 症例. 耳鼻臨床 $78: 669-6741985$.

2）大島清史 : 過去の放射線治療に誘発されたと考 えられる悪性血管内皮腫の 1 症例. 日耳鼻 89 : 17151986.

3) Rao, K.K., Kumar, H.N. et al: Primary haemangiosarcoma of the tongue. Int $\mathrm{J}$ Oral Maxillofac Surg 15 : 489-491 1986.

4) Crymes, T., Taylor, R.G. et al: Angiosarcoma metastatic to the tongue: report of case. J Oral Surg 24 : 63-66 1966.

5) 内田安信, 河合 幹, 他編：䫟口腔外科診断治 療体系, 講談社, 東京 : 1991, 582 .

6）野谷健一, 北田秀昭, 他：舌にみられた悪性血 管内皮腫の 1 例. 口科誌 $38: 477-4821989$.

7) 石川悟朗, 秋吉正豊 : 口腔病理学 II. 永末書店, 京都, 1971, 1033.

8) Stout, A.P.: Hemangioendothelioma. A tumor of blood vessels featuring vascular endothelial cells. Ann Surg 118: 445-464 1943.

9）木村哲二：血管性腫瘍の組織像. 臨床病理 6 : 265-279 1958 .

10）猿田隆夫：Malignant Hemangioendothelioma 皮席臨床 $19:$ 717-722 1977.

11）野坂保次, 長田憲二郎：希有な喉頭悪性血管内 皮腫の 1 症例. 耳喉 $39: 495-4991967$.

12) Farr, H.W., Carandang, C.M., et al.: Malignant vascular tumors of the head and neck. Am J Surg 120 ( 4 ) : 501-504 1970.

13) MaCarthy, W.D. and Pack, G.T.: Malignant blood vessel tumors. A report of angiosarcoma and Kaposi's sarcoma. Surg Gynec \& Obst 91 : 465-482 1950.

14) Shklar, G. and Meyer, I.: Vascular tumors of the mouth and jaws. Oral Surg 19 : 335-358 1965.

15）清水源一郎, 村上栄一郎, 他 : 血管内皮肉腫と 考えられる1例. 診療 $8: 1047-10511955$.

16）前山 厳, 佐藤三郎, 他：骨の血管内腫につい て. 整形外科 $16: 7331965$.

17）鍋谷秀信, 堀田文雄, 他 : 上顎に発生した血管 肉腫の 1 例. 日口外誌 $28: 1132-11381982$. 